\title{
Makarewicz a Liszt. Próba analizy porównawczej
}

I. „Na Liszcie studiować można wpływ rasy, przebijającej się mimo wychowania wśród rasy innej i mimo przymieszki krwi obcej; w zachowaniu się i wzięciu jako człowieka, jego działalności naukowej, jego wystąpieniach publicznych, w słowie i piśmie czuć gorącą krew Madziarów, prącą do czynu, do zmiany, do ruchu" - ta osobista ocena Juliusza Makarewicza, absolwenta Uniwersytetu Jagiellońskiego, dopiero co doktoryzowanego, odbywającego podróż stypendialną po Niemczech, otwierała w 1896 r. jego recenzję podręcznika twórcy socjologicznej szkoły prawa karnego w Europie - Franza von Liszta (1851-1919). Makarewicz, mimo młodego wieku (liczył zaledwie 24 lata) miał pełne prawo do wyrażenia podobnej opinii na temat uczonego znanego z niepospolitej osobowości i ogromnego temperamentu, tym bardziej, że dobrze poznał profesora Liszta (liczącego sobie wówczas 45 lat) w Halle, gdzie uczestniczył - podobnie jak dziesiątki innych młodych adeptów prawa z Niemiec i innych krajów - w słynnym Seminarium kryminalistycznym². Franz von Liszt, urodzony i wykształcony w Wiedniu, w 1879 r. rozpoczął karierę akademicką w Cesarstwie Niemieckim, która ostatecznie zaprowadziła go na szczyty - katedrę w Berlinie oraz ławy Reichstagu3 ${ }^{3}$.

1 J. Makarewicz, Dr. Franz von Liszt, Lehrbuch des Deutschen Strafrechts. Siebente durchgearbeitete Auflage. Erster Teil, Berlin 1895, Przegląd Prawa i Administracji 1896, s. 329.

2 Por. interesujący i pozytywny opis seminarium halleńskiego: S. Posner, Seminarium prawa karnego w Halle, Gazeta Sądowa Warszawska 46 (1895), s. 730-732.

${ }^{3}$ Biografię Liszta por. H. Ostendorf, Von der Rache zur Zweckstrafe. 100 Jahre Marburger Programm von Franz von Liszt, Frankfurt am Main 1982, s. 7-10. W tym samym opracowaniu (s. 13-17) krótka, merytoryczna ocena dorobku uczonego. Por. obszerne opracowania na temat postaci i dzieła Liszta: Gedächtnisschrift für Franz von Liszt zur 50. Wiederkehr seines Todestages am 21. Jun. 1919, zawarte w specjalnym tomie niemieckiego czasopisma „Zeitschrift für die gesamte Strafrechtswissenschaft" (dalej: ZStW) 81 (1969). W literaturze polskiej postać i dorobek Liszta nie są bliżej znane. Autorzy opracowań historyczno-prawnych czy prawniczych ograniczają się do krótkich wzmianek na temat osoby i dorobku niemieckiego uczonego - por. J. Warylewski, Kierun- 
Recenzja Makarewicza dotyczyła siódmego wydania podręcznika niemieckiego prawa karnego pióra Liszta. Należy w tym miejscu przypomnieć, że podręcznik ten był bezdyskusyjnie najbardziej popularny w Niemczech do lat dwudziestych XX w. W latach 1881-1932 doczekał się w sumie 26 wydań; został też przetłumaczony na języki obce ${ }^{4}$. Do jego sukcesu przyczyniła się m.in. prosta systematyka, oparta na naturalistycznym pojęciu czynu oraz formach zjawiskowych przestępstwa ${ }^{5}$. Warto podkreślić, że sam Liszt wypowiedział się na temat swego podręcznika dość wstrzemięźliwie, wręcz sarkastycznie, wskazując, że stworzył go tylko po to, by zachować własny autorytet naukowy w oczach kolegów ${ }^{6}$.

Treści zawarte w zrecenzowanej przez Makarewicza książce pochodziły spod pióra dojrzałego niemieckiego uczonego, który kilkanaście lat wcześniej wystąpił z radykalnym programem odnowy prawa karnego - tzw. Programem marburskim (1882). Liszt wygłosił swe credo na uniwersytecie w Marburgu $\mathrm{w}$ ramach wykładu inauguracyjnego, związanego z objęciem katedry, a następnie opublikował swój tekst, zatytułowawszy go „Der Zweckgedanke im Strafrecht"7. Z Programu marburskiego i dalszych opracowań Liszta wyłaniał się obraz jego koncepcji, które najkrócej można scharakteryzować w trzech zasadniczych punktach ${ }^{8}$. Primo, niemiecki uczony zdecydowanie przesunął uwagę doktryny z przestępstwa na przestępcę; przestępstwo opisywał jako zachowanie szkodliwe społecznie i zarazem społecznie uwarunkowane, a zatem ujmował je socjologicznie, co stanowiło novum. Secundo, zalecał nauce prawa karnego badanie przyczyn przestępczych zachowań, wskazując zwłaszcza na konieczność uprawiania kryminologii i penologii, a z punktu widzenia przyszłych potrzeb - polityki kryminalnej. Tertio, zbudował teorię kary

ki i szkoły w nauce prawa karnego, [w:] A. Marek (red.), System prawa karnego, t. 1, Warszawa 2010, s. 77-78.

${ }^{4}$ Po śmierci Liszta w 1919 r. wydawanie podręcznika kontynuował jego najmłodszy uczeń Eberhard Schmidt.

5 Por. F.M. Conde, Das Erbe Franz von Liszts, [w:] F. Herzog, U. Neumann Festschrift für Winfried Hassemer, Heidelberg 2010, s. 535-558. Na marginesie zaznaczyć muszę, że dzieło liczące mniej więcej 700 stron zaopatrzone było w setki odesłań do literatury przedmiotu, umieszczonych pod nagłówkiem każdego punktu (nazwanego paragrafem) lub w przypisach, a ponadto w zwięzłe zarysy historyczne każdej przedstawianej instytucji części ogólnej lub szczególnej.

${ }^{6}$ F. v. Liszt, Die Zukunft des Strafrechts, [w:] idem, Strafrechtliche Aufsätze und Vorträge, t. 2, s. 1, 23: „(um seine) durch den Kampf um die Umgestaltung der Gesetzgebung geschwächte wissenschaftliche Autorität (seinen) Kollegen gegenüber aufrecht zu erhalten”.

${ }^{7}$ W. Naucke, Die Kriminalpolitik des Marburger Programms 1882, [w:] idem, Über die Zerbrechlichkeit des rechtsstaatlichen Strafrechts, Baden-Baden 2000, s. 223. Por. dostępne wydania Programu marburskiego: Der Zweckgedanke im Strafrecht, ZStW 3 (1883), s. 1-47 albo F. v. Liszt, Strafrechtliche Aufsätze und Vorträge (dalej: AuV), t. 1, Berlin 1905, s. 126 i n.

${ }^{8}$ Zaproponowane przeze mnie punkty wskazujące na główne idee Franza von Liszta są hasłowe i wybiórcze, ponieważ koncepcje Liszta nie są bliżej znane w polskiej literaturze historyczno-prawnej czy prawniczej. Taka wskazówka wydaje mi się jednak konieczna w tym miejscu jako tło dla dalszych, szczegółowych już analiz. 
zdominowaną przez ideę celowości; przekonywał, że kara musi być społecznie pożyteczna, a możliwe cele kary sprowadzał do odstraszenia (przestępców przypadkowych), zabezpieczenia (sprawców niepoprawnych), poprawy (przestępców zdatnych do poprawy). Swoje credo polityczno-kryminalne Liszt wyrażał także w skróconym haśle: „unieszkodliwienie niepoprawnych, poprawa zdatnych do poprawy”. W ten sposób niemiecki profesor wszedł do historii prawa jako ojciec prewencji szczególnej.

Należy z góry podkreślić, że Liszt w ciągu 40 lat swej pracy na niemieckich uniwersytetach, szeroko zakrojonej działalności organizacyjnej, seminaryjnej, edytorskiej ${ }^{10}$, międzynarodowej (zwłaszcza w ramach Międzynarodowego Związku Kryminalistycznego ${ }^{11}$ ) rozwijał oraz modyfikował swe koncepcje. Dostrzegał to już młody Makarewicz, pisząc we wspomnianej recenzji niemieckiego podręcznika, jak Liszt zmieniał swe przekonania ${ }^{12}$. Makarewicz akceptował taki stan rzeczy ${ }^{13}$.

Celem mojego opracowania jest próba nowego spojrzenia na kilka wybranych instytucji części ogólnej prawa karnego i uzyskanie odpowiedzi na

9 Por. T. Stäcker, Die Franz von Liszt-Schule und ihre Auswirkungen auf die deutsche Strafrechtswissenschaft, Baden-Baden 2012, s. 28-29. Ze starszej literatury przedmiotu por. E. Schmidt, Anselm von Feuerbach und Franz von Liszt, Monatsschrift für Kriminalbiologie und Strafrechtsreform 33 (1942), s. 216-217.

${ }^{10}$ Oprócz długiego szeregu rozpraw, podręcznika oraz monumentalnego wydawnictwa Vergleichende Darstellung des deutschen und ausländischen Strafrechts, Liszt był współredaktorem nowego czasopisma „Zeitschrift für die gesamte Strafrechtswissenschaft”, które - zgodnie z nazwą - obejmowało całość (niem. gesamt) dyscyplin penalnych, w tym zwłaszcza kryminologię, procedurę karną, politykę kryminalną itd.

${ }^{11}$ Internationale Kriminalistische Vereinigung została przez Liszta założona w 1889 r. wspólnie z Belgiem Prinsem i Holendrem van Hamelem. Organizacja ta działała faktycznie do I wojny światowej. Spośród Polaków należeli do niej E. Krzymuski, A. Moldenhawer, W. Ostrożyński, J. Rosenblatt, J. Makarewicz i prawdopodobnie S. Budziński - por. M. Paszkowska, Nauka prawa karnego w środowisku ,Gazety Sadowej Warszawskiej” (1873-1918), Warszawa 2010, s. 198. Por. najnowsze monografie na temat organizacji: E. Bellmann, Die Internationale Kriminalistische Vereinigung (1889-1933), Frankfurt am Main 1994; L. Radzinowicz, The Roots of the International Association of Criminal Law and their Significance. A Tribute and a Re-assessment on the Centenary of the IKV, Freiburg 1991.

12 Zdaniem Makarewicza Liszt w pierwszym wydaniu podręcznika był „,zapalonym zwolennikiem teorii norm Bindinga", którą następnie porzucił; podobnie miał początkowo okazać zapał dla tez szkoły antropologicznej, od których się następnie zdystansował. Recenzent doszedł do wniosku o pewnej naiwności niemieckiego uczonego, podsumowując: „, z tego względu zupełnie zasłużył sobie Liszt na przydomek, który Lucchini daje szermierzom nowej szkoły, il semplicisto del diritto penale" (s. 330 recenzji wskazanej w przypisie 1).

13 „Dalecy jesteśmy od tego, by Liszta za jego pociąg do wszystkiego co nowe, co rokuje zmianę i postęp, wstręt do zastoju i szablonu, tendencje nowatorskie, potępiać - przeciwnie raczej za zasługę je poczytujemy [...]" - s. 330 recenzji wskazanej w przypisie 1. Chociaż Makarewicz chwalił samego Liszta, poddał krytyce jego uczniów, m.in. uczonych skupionych wokół Roberta von Hippla, o których napisał m.in., że są skłonni „do najdziwniejszych konstrukcji, byle jak najdalej od stanowiska życiowego" - por. J. Makarewicz, Kodeks karny z komentarzem, Lwów 1935, s. 84-85. Stosunek Polaka do przedstawicieli doktryny klasyfikowanych jako „trzecia szkoła” nie jest jednak przedmiotem analizy w ramach niniejszej rozprawy. 
pytanie, czy i w jakim zakresie tezy Liszta znalazły wprost akceptację Makarewicza. Nie sposób w ramach niewielkiej rozprawy przeanalizować całości interesujących zagadnień, dlatego na potrzeby niniejszego tekstu wybrałam następujące kwestie: ustawę karną, typologię przestępców, cele kary oraz środki zabezpieczające.

Ze względu na ograniczone ramy tego opracowania, poza analizą pozostawiłam z konieczności szereg innych ciekawych, zbieżnych u obu uczonych wątków, w tym m.in. zagadnienie wolnej woli człowieka, kwestię stosowania kary pozbawienia wolności, specjalne zasady odpowiedzialności nieletnich, usamodzielnienie prawa wykroczeń, problem rozwoju nauk pokrewnych i pomocniczych prawa karnego. Na marginesie chciałabym jedynie zwięźle zasygnalizować, że zarówno Liszt, jak i Makarewicz postulowali wyłączenie z nauki prawa karnego sporu o istnienie wolności woli człowieka ${ }^{14}$. Co do kar pozbawienia wolności, niemiecki uczony był przeciwnikiem kar krótkoterminowych, a polski - ich krytykiem ${ }^{15}$. Obaj profesorowie walczyli o reformę odpowiedzialności karnej nieletnich i środki wychowawcze dla tej grupy sprawców ${ }^{16}$. Obaj postulowali również uregulowanie wykroczeń w odrębnej, pozakodeksowej ustawie ${ }^{17}$. I niemiecki, i polski profesor apelowali wreszcie o rozwój nauk pomocniczych prawa karnego, zwłaszcza kryminologii, przy czym sami chętnie i swobodnie korzystali z dorobku dyscyplin empirycznych,

${ }^{14}$ Liszt w swym podręczniku, począwszy od wydania z 1914 r., postulował natomiast tzw. naukowy determinizm, czyli ocenę przyczyn, a zwłaszcza motywacji sprawcy każdego przestępstwa - por. R. Seidl, Der Streit um den Strafzweck zur Zeit der Weimarer Republik, Bern-Frankfurt am Main 1974, s. 19. Makarewicz twierdził, że zagadnienie to jest kwestią filozoficzną lub religijną i nie może być rozstrzygnięte w sposób stanowczy - por. idem, Prawo karne. Wykład porównawczy z uwzględnieniem prawa obowiąującego w Rzeczypospolitej Polskiej, Lwów-Warszawa 1924, s.117; idem, Kodeks..., s. 76.

${ }^{15}$ Liszt, Der Zweckgedanke, s. 41 zalecał, aby kary pozbawienia wolności nie były krótsze niż 1 rok, dodając: „Nie ma nic bardziej niemoralnego i niedorzecznego niż nasze krótkoterminowe kary pozbawienia wolności orzekane wobec praktykantów na drodze przestępstwa (Lehrlinge auf den Bahn des Verbrechens)”. Makarewicz wielokrotnie powtarzał: „Kara pozbawienia wolności rzadko kogo poprawia, wielu już zepsuła do gruntu" - por. idem, Kodeks..., s. 35. Polski uczony z zadowoleniem odnotowywał zmiany idące w kierunku warunkowego zawieszania wykonania kary pozbawienia wolności oraz zastępowania jej przez grzywnę lub środki zabezpieczające - por. ibidem, s. 35, 138, 165. Por. też A. Grześkowiak, Kara w poglądach Juliusza Makarewicza, [w:] A. Grześkowiak (red.), Prawo karne w poglądach Profesora Juliusza Makarewicza, Lublin 2005, s. $273-274$ i 276.

${ }^{16} \mathrm{~W}$ niemieckiej literaturze przedmiotu powszechnie przypisuje się doktrynie Liszta wpływ na wydanie osobnej ustawy o sądach dla nieletnich (Jugendgerichtsgesetz), która ukazała się w 1923 r., czyli 4 lata po śmierci uczonego - por. H. Ostendorf, op. cit., s. 17-18. Makarewicz zdołał - jak wiadomo - wpłynąć bezpośrednio na nowoczesną regulację zasad odpowiedzialności nieletnich w kodeksie karnym z 1932 r. - por. R. Hałas, Zasady odpowiedzialności nieletnich wedlug Juliusza Makarewicza, [w:] A. Grześkowiak (red.), op. cit., s. 311-324.

${ }^{17}$ Liszt postulował wyłączenie wykroczeń z prawa karnego - por. R. Seidl, op. cit., s. 23. Makarewicz stanowczo, nawet wbrew przeważającej opinii innych uczonych, propagował osobny „kodeks policyjny”, jak go nazywał - por. J. Makarewicz, Powrotna fala (Projekt ustawy o wykroczeniach), Ruch Prawniczy, Ekonomiczny i Socjologiczny 10, półrocze 2 (1930), s. 475-501. 
m.in. psychiatrii, psychologii, statystyki i innych ${ }^{18}$. Wspomniane wyżej kwestie, jak też inne ciekawe wątki nauki o przestępstwie, winie i karze, pragnę uczynić przedmiotem odrębnej analizy i przedstawić w kolejnym opracowaniu $^{19}$.

II. Jedną z najbardziej znanych wypowiedzi Liszta było stwierdzenie, że kodeks karny stanowi magna charta dla przestępcy, innymi słowy, że ustawa karna daje gwarancję uprawnień dla sprawców czynów karygodnych. Myśl ta pojawiła się w koncepcjach niemieckiego profesora w końcu XIX w. w obszernej rozprawie zatytułowanej Deterministyczni przeciwnicy kary celowej ${ }^{20}$. Przed wygłoszeniem omawianej tezy uczony przypomniał, że prawo karne jest wyrazem władzy karzącej państwa, która ze względu na ochronę wolności indywidualnej ma ograniczony charakter. Zasady nullum crimen, nulla poena sine lege nazwał „bastionem” obywatela w stosunku do wszechogarniającej władzy państwowej, którą porównywał do Lewiatana ${ }^{21}$. Zakończył tę kwestię stwierdzeniem, które na zawsze weszło do obiegu naukowego: „Choć to brzmi paradoksalnie: kodeks karny jest magna charta przestępcy” (,,So paradox es klingt: das Strafgesetzbuch ist die magna charta des Verbrechers") ${ }^{22}$.

18 Makarewicz, moim zdaniem nazbyt jednostronnie, krytykował Liszta za to, że w małym stopniu wykorzystał w swoim podręczniku takie dyscypliny pomocnicze jak socjologia czy historia prawa karnego, a także metodę ewolucyjno-porównawczą (recenzja, s. 331). Rzeczywiście, w niemieckim podręczniku charakterystyka wspomnianych zagadnień zajęła tylko kilka stron. Jednak w powszechnej opinii badaczy Liszt przez całe życie propagował w swej twórczości „naukę prawa karnego w całości”, obejmującą obok dogmatyki - kryminologię, politykę kryminalną, penologię, historię prawa karnego i inne - por. A. Koch, Binding vs. v. Liszt - Klassische und moderne Strafrechtsschule, [w:] E. Hilgendorf, J. Weitzel (red.), Der Strafgedanke in seiner historischen Entwicklung. Ringvorlesung zur Strafrechtsgeschichte und Strafrechtsphilosophie, Berlin 2007, s. 133-134; por. też wyżej przypis 10. Sam Makarewicz w obu swoich podręcznikach (por. przypisy 14 i 32) poświęcił omawianym dyscyplinom (zwłaszcza statystyce kryminalnej) i rezultatom ich badań kilkadziesiąt stron. W komentarzu do kodeksu karnego odwoływał się do nich rzadziej, czasem do psychologii lub psychopatologii (Kodeks..., s. 28, 76), psychiatrii (ibidem, s. 203), statystyki (ibidem, s. 170, 206).

19 Dokonana w ramach niniejszej pracy analiza porównawcza była możliwa dzięki krótkim pobytom badawczym w Niemczech. Pragnę podziękować zwłaszcza Bawarskiej Kancelarii Państwowej (Bayerische Staatskanzlei) za umożliwienie mi przeprowadzenia w Würzburgu odpowiednich studiów nad dorobkiem Franza von Liszta.

${ }^{20}$ Die deterministischen Gegner der Zweckstrafe (1893), AuV, t. 2, Berlin 1905, s. 25-74. Wszelkie zawarte w niniejszym opracowaniu przekłady tytułów prac Liszta lub ich fragmentów w thumaczeniu własnym autorki.

${ }^{21}$ Ibidem, s. 60: „Strafrecht ist (...) die rechtlich begrenzte Strafgewalt des Staates. Rechtlich begrenzt nach Voraussetzungen und Inhalt; rechtlich begrenzt im Interesse der individuellen Freiheit. Nullum crimen sine lege, nulla poena sine lege. Diese beiden Sätze sind das Bollwerk des Staatsbürgers gegenüber der staatlichen Allgewalt: sie schützen den Einzelnen gegen die rücksichtslose Macht der Mehrheit, gegen den Leviathan".

${ }^{22}$ Ibidem. Niektórzy współcześni krytycy Liszta oceniają jednak, że już w tej samej rozprawie uczony ograniczył omawianą zasadę, wskazując, że wolność jest pojęciem względnym, definiowanym przez państwo. Por. S. Ehret, Franz von Liszt und das Gesetzlichkeitsprinzip. Zugleich ein Bei- 
Myśl niemieckiego uczonego miała liberalny wydźwięk - wskazywała na konieczność obrony indywidualnej wolności przed ingerencją państwa.

Tezę o ustawie karnej jako magna charta dla sprawcy przestępstwa powtarzał Liszt wielokrotnie ${ }^{23}$. Na początku XX w. w czasie toczących się w Niemczech prac nad reformą prawa karnego ${ }^{24}$ podkreślał, że kodeks karny w dalszym ciągu powinien być magna charta przestępcy, a zadaniem państwa jest - w określonych granicach - ochrona porządku prawnego za pomocą kary. Uczony pisał:

Kodeks karny niezmiennie powinien być magna charta przestępcy: lecz w obrębie tak wytyczonych granic władzy państwowej przypada karze dalsze zadanie - ochrony dóbr kulturowych narodu, uznanych przez porządek prawny, przed atakami ze strony przestępcy ${ }^{25}$.

Omawianemu lejtmotywowi magna charta nie towarzyszyło w teorii Liszta pogłębienie zasady nullum crimen sine lege. Wręcz przeciwnie - uczony $\mathrm{w}$ istocie redukował ją do zasady nulla poena sine lege $e^{26}$. W pierwszych latach swej działalności naukowej nie poświęcał większej uwagi fundamentalnemu nullum crimen. Nie wskazywał, że prawo karne powinno być pewne,

trag wider die Gleichsetzung von Magna-charta-Formel und Nullum-crimen-Grundsatz, Frankfurt am Main 1996, s. 78-80.

${ }^{23}$ F. v. Liszt, Über den Einfluss der soziologischen und anthropologischen Forschungen (1893), AuV, t. 2, Berlin 1905, s. 75-93; tu s. 80: „Nach meiner Meinung ist, so paradox es klingen mag, das Strafgesetzbuch die magna charta des Verbrechers. Er schützt nicht die Rechtsordnung, nicht die Gesamtheit, sondern den gegen diese sich auflehnenden Einzelnen". Por. idem, Die Deliktsobligationen im System des Bürgerlichen Gesetzbuchs. Kritische und dogmatische Randbemerkungen, Berlin 1898, s. 4: „Der Satz 'nullum crimen sine lege' soll die Freiheit des einzelnen Staatsbürgers schützen gegenüber der Allgewalt des Staates. In diesem Sinne habe ich das Strafgesetz bezeichnet als die magna charta des Verbrechers". Por. komentarz S. Ehret, op. cit., s. 87. Warto w tym miejscu dodać i podkreślić, że omawiana teza o magna charta nie została włączona do podręcznika Liszta.

${ }^{24}$ Liszt nie został zaproszony do udziału w niemieckich pracach kodyfikacyjnych - nie powołano go ani do komisji z 1906 r., ani tej z 1911 r. Na to jawne upokorzenie zareagował tzw. projektem alternatywnym z 1911 r., który współtworzył razem z prawnikami Goldschmidtem, Kahlem i von Lilienthalem. W kolejnych wydaniach swego podręcznika umieszczał obszerny rozdział „Historia prawa karnego", w którym znajdowała się zarówno charakterystyka i bibliografia kodeksu karnego Rzeszy, jak i najnowszych prac nad reformą prawa karnego w Niemczech, Europie i na świecie. Por. dla przykładu F. v. Liszt, Lehrbuch (1912), s. 45-72.

25 „Nach wie vor soll das Strafgesetzbuch die magna charta des Verbrechers sein: aber innerhalb der so der Staatsgewalt gesteckten Grenzen fällt der Strafe die weitere Aufgabe zu, die Kulturgüter des Volkes, wie sie durch die Rechtsordnung anerkannt sind, gegen die Angriffe des Verbrechers zu schützen" - por. Strafrechtsreform (in Deutschland) (1911), [w:] Handbuch der Politik, t. 3, Berlin-Leipzig 1921, s. 203.

${ }^{26}$ Wskazują na to w szczególności zalecenia uczonego co do „nieoznaczonego wyroku karnego", w którym sędzia w ogóle nie miał określać czasu kary pozbawienia wolności, pozostawiając tę decyzję władzom administracyjnym, które miały oceniać osiągnięcie celów kary. Por. S. Ehret, op. cit., s. 83. 
określone przez ustawodawcę. Nie twierdził też, że związanie ustawą karną jest gwarancją ochrony jednostki. Poprzestawał na uwagach historyczno-prawnych przypominających, że zasada nullum crimen stanowi trwały rezultat walki stoczonej o reformę prawa karnego przez pisarzy Oświecenia. Ponadto podkreślał, bazując na przepisach niemieckiego kodeksu karnego, że jedynym źródłem prawa karnego jest prawo pisane oraz że prawo karne nie może działać wstecz ${ }^{27}$. Zasadę nulla poena sine lege wyartykułował dopiero w późniejszych wydaniach swego podręcznika, wskazując, że karane może być tylko zachowanie, które „odpowiada jednemu ze znamion dokładnie opisanych i wyczerpująco wskazanych w ustawie"28. Uczony nigdy nie pisał, że omawiane reguły są zasadami prawa karnego praworządnego i liberalnego ${ }^{29}$.

Inaczej postąpił Juliusz Makarewicz, który pisząc swój podręcznik kilkanaście lat później, nie wahał się przed bezpośrednim wskazaniem zasady nullum crimen sine lege jako gwarancji praworządności, argumentując:

Głównym motywem przemawiającym za nią jest ustalenie w praworządnym państwie warunków, pod którymi można obywatela karać, zapobiega się w ten sposób samowoli ze strony organów państwowych, które choćby w todze sędziego i choćby pod pozorem dobra powszechnego mogłyby służyć celom bądź to kamaryli otaczającej panującego, bądź wpływowych stronnictw politycznych ${ }^{30}$.

Gwarancyjnej funkcji prawa karnego poświęcił polski uczony pewne odrębne opracowanie powstałe na bazie uroczystego odczytu wygłoszonego we Lwowie w $1936 \mathrm{r}^{31}$

Uznanie w oczach Makarewicza znalazła natomiast teza Liszta o kodeksie karnym jako magna charta przestępcy. W podręczniku polski profesor wyjaśniał wprost:

mimo pewnych niedogodności w społeczeństwach nowożytnych $[\ldots]$ zdaje się zwyciężać zasada, że ustawa karna być powinna kartą wolności (magna charta) jednostki naruszającej interesy społeczne: jeżeli naruszenie na karcie tej wymieniono, niech nastąpi kara, jeżeli nie ma na karcie wzmianki, kary być nie może ${ }^{32}$.

${ }^{27}$ Das deutsche Reichsstrafrecht, wyd. 1, Berlin-Leipzig 1881, s. 24-25 i s. 48. Por. S. Ehret, op. cit., s. 72.

${ }^{28}$ F. v. Liszt, Lehrbuch des deutschen Strafrechts, wyd. 21/22, Berlin 1919, s. 182.

29 S. Ehret, op. cit., s. 175. Autorka ta dochodzi do kontrowersyjnego wniosku, że stanowisko Liszta nie było tak liberalne, jakby się to wstępnie wydawało, że w jego programie widoczne są tony rygoryzmu czy wręcz autorytaryzmu - por. ibidem, s. 91.

30 J. Makarewicz, Prawo karne. Wyktad..., s. 9.

31 Prawo karne i prawa obywatela, odczyt wygloszony dnia 20 stycznia 1936 r. w Auli Uniwersytetu Jana Kazimierza we Lwowie w czasie Akademii zwiazanej z 275. rocznica zalożenia Uniwersytetu, Lwów 1936.

32 J. Makarewicz, Prawo karne. Wykład..., s. 10. Dosłownie tak samo pisał uczony już w swym pierwszym podręczniku: Prawo karne ogólne, Kraków 1914, s. 6. 
Podczas wspomnianego odczytu we Lwowie uczony wskazywał, że prawo karne zawarte w ustawach stanowi ,magna charta przestępcy [...] zapewnienie, że nie spotka go kara za nic innego, jak tylko za to, co jest przewidziane w kodeksie karnym"33. Komentując ustawową zasadę nulla poena sine lege poenali anteriori, podsumował: „To kategoryczne stwierdzenie odpowiada stanowisku nowożytnego prawa karnego w związku z ujęciem kodeksu karnego jako magna charta obywatela w dziedzinie konfliktów z interesami społeczeństw [...]"34. W innym jeszcze miejscu, analizując stosowanie środków zabezpieczających, Makarewicz - w duchu szkoły socjologicznej - odnosił się do gwarancji swobód obywatelskich i wywodził, że prawo ma ,nie tylko zabezpieczyć społeczeństwo przed szkodliwą jednostką, ale także zabezpieczyć obywatela przed ewentualnym nadużyciem ze strony czynników administracyjnych" 35 . Wskazując na czynniki administracyjne, uczony miał na myśli władze karzące ${ }^{36}$.

III. Liszt zbudował i upowszechnił swą znaną typologię sprawców w nawiązaniu do koncepcji wiedeńskiego profesora Wilhelma Emila Wahlberga (1824-1901), nota bene przedstawiciela klasycznej szkoły prawa karnego ${ }^{37}$. Liszt wyróżnił zatem, analogicznie jak Wahlberg, dwie główne grupy kryminalistów na podstawie zasadniczego kryterium częstotliwości łamania prawa, oddzielając przestępców przypadkowych, zwanych też chwilowymi (niem. Gelegenheitsverbrecher oder Augenblicksverbrecher) - od notorycznych (niem. Gewohnheitsverbrecher; Zustandsverbrecher ${ }^{38}$ ). Typologię tę rozwinął, dzieląc sprawców notorycznych na osoby nadające się do poprawy (niem. Besserungsfähigen $^{39}$ ) i nie nadające się do tego (niem. Unverbesserlichen ${ }^{40}$ ). W tym miejscu wskazać też należy, że na trójpodziale typów przestępnych

33 J. Makarewicz, Prawo karne i prawa..., s.105.

34 J. Makarewicz, Kodeks..., s. 43.

35 J. Makarewicz, Prawo karne i prawa ..., s. 99.

${ }^{36}$ F. Ciepły, Środki zabezpieczające wedlug koncepcji Juliusza Makarewicza, [w:] A. Grześkowiak (red.), op. cit., s. 293.

${ }^{37}$ F. v. Liszt, Lehrbuch des Deutschen Strafrechts, wyd. 18/19, Berlin 1912, s. 79 określił klasyfikację Wahlberga mianem ,przełomowej” (bahnbrechend). Por. M. Frommel, Franz von Liszt, Neue Deutsche Biographie, t. 14, s. 705; S. Galassi, Kriminologie im Deutschen Kaiserreich: Geschichte der gebrochenen Verwissenschaftlichung, Stuttgart 2004, s. 353. Na temat postaci i teorii Wahlberga, a także jego najważniejszego w omawianym kontekście dzieła pt. Das Prinzip der Individualisierung in der Strafrechtspflege, Wien 1869 - por. W. Brauneder (red.), Juristen in Österreich (1200-1980), Wien 1987, s. 171-176.

${ }^{38}$ F. v. Liszt, Lehrbuch (1912), s. 79; idem, Lehrbuch des Deutschen Strafrechts, wyd. 24, Berlin 1922, s. 11. Warto odnotować na marginesie, że we współczesnej niemczyźnie termin $G e-$ wohnheitsverbrecher/ Gewohnheitstäter ustąpił miejsca pojęciu Hangtäter - por. A. Kilian, Wörterbuch der Rechts- und Wirtschaftssprache, cz. 2, München 1996, s. 295.

39 F. v. Liszt, Lehrbuch (1912), s. 79 (w innych miejscach: verbesserliche/resozialisierbare Gewohnheitsverbrecher).

${ }^{40}$ Ibidem (w innych miejscach także: unresozialisierbare Verbrecher). 
na sprawców przypadkowych, zdatnych do poprawy i niepoprawnych oparł Liszt różnorodność środków zwalczania przestępczości, o której będzie mowa dalej. Niezależnie od wymienionych grup podstawowych, niemiecki profesor wyróżnił osobną kategorię sprawców przestępstw zawodowych (gewerbsmäßige; berufsmäßige; professionele Verbrechen), które opisywał jako szczególnie częste i niebezpieczne, dodając, że nie ograniczają się już one jak dawniej - do deliktów przeciwko własności ${ }^{41}$.

Szerzej nauki o typologii sprawców niemiecki uczony nie rozwinął, w szczególności nie podał dalszych przydatnych kryteriów pozwalających zaszeregować delikwentów do jednej z trzech wskazanych grup ${ }^{42}$. Stało się to źródłem wątpliwości i krytyki koncepcji Liszta ${ }^{43}$.

Stosunek Liszta do przestępców notorycznych był bardzo surowy ${ }^{44}$. Uczony zalecał ich unieszkodliwianie poprzez izolację na czas nieokreślony w ciężkich zakładach karnych. W zachowanej korespondencji Liszta, pochodzącej z $1880 \mathrm{r}$. i skierowanej do jego współpracownika, znalazły się następujące słowa:

Więzienie zabezpieczające dla notorycznego przestępcy: dom pracy połączony z drylem wojskowym bez żadnych ceregieli i to tak tanio, jak tylko możliwe, nawet jeśli te dranie zginą. Nieodzowna kara chłosty [...]. Przestępcę notorycznego $[\ldots]$ trzeba unieszkodliwić i to na jego, a nie na nasz koszt. Dostarczanie mu wyżywienia, powietrza, ruchu itd. według racjonalnych zasad to nadużycie podatników ${ }^{45}$.

Nawet jeśli wziąć poprawkę na język uczonego, znanego z retorycznych, emocjonalnych i plastycznych wypowiedzi ${ }^{46}$, jego postawę należy ocenić jako rygorystyczną.

41 Ibidem.

42 Ibidem. Tu Liszt zaledwie jednym zdaniem wskazał, że przestępca przypadkowy to ,nieposzlakowany dotychczas sprawca, który działa pod wpływem chwilowej usilnej pobudki lub przytłaczającego trudnego położenia", a dalej - w dwóch zdaniach - opisał przestępcę notorycznego jako człowieka o specyficznej, trwałej osobowości, którą cechuje ,brutalne grubiaństwo, pozbawione uczuć okrucieństwo, tępy fanatyzm, nierozważna lekkomyślność, wstręt do pracy nie do przezwyciężenia, nieprzyzwoitość seksualna”. W późnych wydaniach podręcznika dodał do tego katalogu jeszcze pijaństwo - por. F. v. Liszt, Lehrbuch (1922), s.11.

43 Jeden z przeciwników naukowych Liszta Johannes Nagler, uczeń Karla Bindinga i zarazem zdecydowany obrońca szkoły klasycznej, wskazywał generalnie, że szkoła socjologiczna nie wyszła ponad niejasne wyznaczniki oparte raczej na intuicji niż na racjonalnych przesłankach, a sięgała przy tym do pojedynczych przypadków, traktując je w izolacji - por. J. Nagler, Die Verständigung der Strafrechtsschulen, Gerichtssaal 70 (1907), s. 32, http://dlib-zs.mpier.mpg.de/mj/kleioc/0010/ exec/smapage/\%222173686_7000\%2b1907_0013\%22 (dostęp: 12.10.2014).

44 Znane są wypowiedzi Liszta, zawarte m.in. we wspomnianej wyżej pracy Die deterministischen Gegner der Zweckstrafe (por. przypis 20), świadczące o tym, że uczony gotów był podobnie traktować przestępców z nawyknienia i chorych psychicznie - por. A. Koch, op. cit., s. 138-139.

45 A. Koch, op. cit., s. 136.

46 T. Stäcker, op. cit., s. 20. 
Makarewicz nie przyjął dosłownie Lisztowskiego trójpodziału przestępców, natomiast bez skrępowania i wielokrotnie posługiwał się, rozpowszechnionym przez Liszta, pojęciem niepoprawnego przestępcy ${ }^{47}$. Tłumaczył, że jest to sprawca, ,przy którym stwierdzamy tendencję do popełniania przestępstw tak silną, że żadne środki karne, prócz chyba kary śmierci, nie są w stanie sprowadzić go z drogi przestępstwa"48. Lwowski uczony usiłował znaleźć uzasadnienie dla typu niepoprawnego przestępcy, po pierwsze, w ,ustroju psychofizycznym sprawcy i w jego charakterze" ${ }^{49}$, po drugie, w przesłance ciągłego, ponownego popełniania przezeń przestępstw, mimo uprzedniego karania, czyli w braku ,przemiany psychicznej na rzecz współżycia społecznego" ${ }^{0}$. Niepoprawnych przestępców identyfikował Makarewicz z „niepożądanymi elementami, wywołującymi niepokój” oraz ,jednostkami niebezpiecznymi"51. Analogicznie jak uczony niemiecki, także polski profesor przeciwstawiał niepoprawnym - sprawców przypadkowych, pisząc o przestępcach ,ze zbiegu okoliczności”, „przejściowych”, „epizodycznych”52.

Makarewicz rozszerzył spojrzenie na przestępców niepoprawnych, których utożsamiał z trzema kategoriami delikwentów: wielokrotnymi recydywistami, przestępcami zawodowymi oraz nałogowymi (inaczej: ,z nawyknienia" ${ }^{53}$. Różnice między nimi wskazał wprost, choć z dogmatycznego punktu widzenia - nie do końca precyzyjnie. Recydywistą nazywał przestępcę, który po odbyciu kary dopuścił się ponownie czynu zabronionego ${ }^{54}$. Odwołując się do statystyki kryminalnej, przypominał, że recydywa jest „niepokojącym zjawiskiem społecznym, dowodzi bowiem, że środki karne stosowane

47 J. Makarewicz, Kodeks..., s. 38. W tym miejscu przypomnieć należy, że pojęcie „niepoprawnego przestępcy" w niespełna 2 lata po wydaniu polskiego kodeksu karnego weszło do urzędowej nomenklatury w tytule i treści Rozporządzenia Ministra Sprawiedliwości z dnia 15 stycznia 1934 r. w sprawie organizacji zakładów dla niepoprawnych przestępców, Dz.U.R.P. Nr 5, poz. 38. Poprzedni adekwatny akt prawny - Rozporządzenie Ministra Sprawiedliwości z dnia 20 czerwca 1931 r. w sprawie regulaminu więziennego (Dz.U.R.P. Nr 71, poz. 577) nie operował jeszcze tą nomenklaturą.

48 J. Makarewicz, Zbrodnia i kara, Lwów 1922, s.79. Por. F. Ciepły, op. cit., s. 297.

49 J. Makarewicz, Kodeks..., s. 27, 183.

50 Ibidem, s. 38. Por. s. 40: „(niepoprawny) dał dowód, że zamknięcie o tym czy innym charakterze nie działa na jego psychikę, ani go nie odstrasza, ani nie poprawia, duchowo wcale go nie zmienia".

51 Ibidem, s. 40-41 oraz 119.

52 Ibidem, s. 36; por. J. Makarewicz, Zbrodnia ..., s. 85 i 146. Ponadto uczony wyróżniał „,przestępców ze sposobności”, tj. osoby popełniające czyny karygodne pod namową lub kierunkiem sprawców zawodowych - por. idem, Wzrost przestępczości w Polsce: ustęp z przemówienia wygłoszonego w Senacie Rz. P. 7 marca 1931 r. (Debata nad budżetem Min. Sprawiedliwości), Przegląd Prawa i Administracji 1931, s.170.

53 J. Makarewicz, Kodeks..., s. 39 („recydywiści itp. [niepoprawni])”, s. 40 („tzw. niepoprawni”).

${ }^{54}$ Ibidem, s.170. Komentując przepisy kodeksowe uczony rozwijał oczywiście temat, wskazując, że chodzi o czyn tego samego lub innego rodzaju. 
do przestępców są bezskuteczne"55. Przestępcą zawodowym był w interpretacji Makarewicza ,człowiek, który dokonywanie przestępstw uznał za stałe źródło dochodów" ${ }^{56}$. Uczony twierdził, że sprawcy tego typu dopuszczają się z reguły przestępstw przeciwko mieniu" ${ }^{57}$. Za bardzo groźną uważał zorganizowaną przestępczość - tworzenie się związków przestępczych, zwłaszcza mafijnych ${ }^{58}$. Miano sprawcy nałogowego, nazywanego też przestępcą z nawyknienia, zarezerwował Makarewicz na określenie człowieka powracającego do przestępstwa ze względu na niezwykle silny przymus psychiczny „żywiołowy pęd do dokonywania przestępstw, bez podkładu zarobkowego"59. Dla ilustracji uczony kazuistycznie wskazywał przestępców seksualnych, maniaków pojedynków, uczestników bijatyk, złodziei sklepowych (zwłaszcza złodziejki), lichwiarzy, oszustów karcianych (,nałogowców szulerów”) ${ }^{60}$. Należy podkreślić, że w pobliżu sprawców niepoprawnych Makarewicz sytuował „włóczęgów uciekających od pracy”, a także narkomanów ${ }^{61}$. Lektura opracowań polskiego profesora dowodzi, że wyjaśniając typy przestępcze, posługiwał się on raczej egzemplifikacją, a nie klasyfikacją na podstawie przyjętych z góry kryteriów rzeczowych.

Na marginesie pragnę zauważyć, że Makarewicz nie zdołał, tak jak i sam Liszt, przezwyciężyć trudności doktrynalnych pojawiających się przy próbie bliższego określenia pojęcia niebezpieczeństwa przestępcy dla porządku

55 Ibidem, s.169-170. Por. J. Makarewicz, Prawo karne. Wyktad..., s. 39: „Najgorzej przedstawia się statystyka tych recydywistów, którzy już pięciokrotnie ponieśli karę; jak a priori przypuszczać należy, skłonni są do powtarzania przestępstw w przyszłości i tak statystyka niemiecka wykazuje, że na 30.507 takich osób w ciągu lat 1894 do 1899 (a więc w ciągu pięciolecia) $71,7 \%$ popełniło nowy czyn karygodny. Była to niewątpliwie kategoria przestępców niepoprawnych".

56 J. Makarewicz, Kodeks..., s. 36, 173. Por. idem, Zbrodnia ..., s. 79-80: „Są to ludzie, którzy żyją przestępstwem, jest to ich żywioł, popełniają je ciągle, ponoszą kary kilkanaście lub kilkadziesiąt razy (...)”. Por. F. Ciepły, op. cit., s. 297.

57 J. Makarewicz, Kodeks..., s. 173.

58 J. Makarewicz, Zbrodnia ..., s. 79-80: „Związki oparte na pisemnych umowach (statutach) (...) trwające od dawna, trudne do wytępienia. (...) jest to społeczeństwo dla siebie, pogrążone w walce z społeczeństwem państwowym".

59 J. Makarewicz, Kodeks ..., s. 36. Nie trzeba podkreślać, że kiedy Makarewicz pisał o „przestępcy nałogowym” lub krótko „nałogowcu”, nie miał oczywiście na myśli narkomanów, których nazywał morfinistami lub kokainistami.

${ }^{60}$ Ibidem, s.173; por. J. Makarewicz, Zbrodnia..., s. 82. Dodawał też: „Przestępca z nawyknienia (nałogowy) może być degeneratem (osobnikiem o zmniejszonej odpowiedzialności)”.

61 J. Makarewicz, Prawo karne, Wyktad..., s. 126; idem, Zbrodnia..., s. 81-82; idem, Kodeks..., s. 183. W tym ostatnim Makarewicz jednym tchem wymieniał sprawców, których w zasadzie nie należy zwalniać warunkowo: „sprawca częściowo anormalny, skłonny do nadużywania trucizn odurzających, włóczęga uciekający od pracy, albo też recydywista”. Żebraków i włóczęgów nazywał uczony „proletariatem przestępczości”, pisząc (Prawo karne, Wykład..., s. 46): „Pamiętać należy, że obok przestępców w wielkim stylu, przestępców właściwych, istnieje jeszcze proletariat przestępności, to są żebracy, włóczęgi. [...] stanowią oni materiał na przestępców [...]. Por. analogicznie: idem, Zbrodnia, s. 145-146. 
prawnego. Swe wywody na temat niebezpiecznych kryminalistów polski profesor ilustrował natomiast przykładami, wskazując m.in. zbrodniarzy godzących w wewnętrzny porządek w państwie (zwłaszcza fałszerzy monet) lub grożących niebezpieczeństwem dla państwa z zewnątrz; przestępców winnych sprowadzenia niebezpieczeństwa powszechnego, w tym sprawców katastrof; osoby niebezpieczne dla otoczenia, grożące bliskim śmiercią; prowodyrów rozruchów, a także - sprawców niepoczytalnych całkowicie lub częściowo ${ }^{62}$. Jako ciekawostkę warto wreszcie odnotować, że w traktacie Zbrodnia i ka$r a^{63}$, zawierającym Makarewiczowskie koncepcje rozwoju przestępstwa, przestępczości i kary, na specjalnych wkładkach znalazło się kilkadziesiąt zdjęć - portretów kryminalistów, o których pisał uczony. Przedstawiały one: kolejno: oszustów, fałszerzy monet, złodziei, oszczercę, winną porzucenia dziecka, morderców i kilka typów ludzi anormalnych. Bez względu na to, kto i dlaczego zadecydował o umieszczeniu tych zdjęć we wspomnianej książeczce, nie ma wątpliwości co do tego, że lwowski uczony te i podobne kategorie przestępców zwykł nazywać jednostkami niebezpiecznymi oraz ,pasożytami społecznymi" ${ }^{6}$.

Makarewicz nie wahał się użyć - w duchu Liszta - sformułowania o celowości „unieszkodliwiania” sprawców niepoprawnych. Pisał m.in.:

Społeczeństwa dawniejsze miały dla takich osobników karę śmierci, która oczyszczała życie społeczne z niebezpiecznych mętów. Społeczeństwo nowożytne ma bardziej humanitarne sposoby walki z takimi przestępcami, ma tzw. środki zabezpieczające, których zadaniem jest odciąć podobne typy od reszty społeczeństwa, odebrać im sposobność dokonywania przestępstw i wykonywania przestępnego zawodu ${ }^{65}$.

Uczony przyjął, jak mi się wydaje nazbyt optymistycznie, następujące założenie: „Wystarczy unieszkodliwić kilka tysięcy ludzi w państwie polskim, by nastała epoka ulgi, by można stwierdzić, że stosunki bezpieczeństwa publicznego w Polsce znacznie się poprawiły" ${ }^{\prime 66}$. Nawet po wejściu w życie polskiego kodeksu karnego lwowski profesor nieodmiennie thumaczył:

62 J. Makarewicz, Kodeks..., s. 202; idem, Prawo karne, Wyktad..., s. 222; idem, Wzrost..., s. $171-173$.

${ }^{63}$ Por. wyżej przypis 48.

${ }^{64}$ J. Makarewicz, Zbrodnia..., s. 79; idem, Prawo karne, Wykład..., s. 294. Co ciekawe, Makarewicz - tak jak Liszt - twierdził, że różnica między przestępcą zawodowym a niepoczytalnym jest nieostra: „Granice między typem zawodowca, obłąkanego i częściowo anormalnego są płynne, wyszukanie ich w każdym konkretnym przypadku jest rzeczą znawców i sądu, natomiast pewnym jest, że są to typy odrębne, wymagające swoistego traktowania" - por. idem, Zbrodnia ..., s. 84. Co do Liszta por. wyżej przypis 44.

65 J. Makarewicz, Wzrost..., s. 167.

${ }^{66}$ Ibidem, s. 168. 
Doświadczenie uczy, że kilka tysięcy osobników stale (aż do przychwycenia) powtarzających przestępstwa nastraja pesymistycznie opinię publiczną. Zdaje się, że to cała wielka armia zbrodniarzy, a to tylko te same jednostki [...] mnożą się w oczach. Trzeba ich unieszkodliwić, a odetchniemy spokojnie ${ }^{67}$.

Z satysfakcją wypowiadał wreszcie opinię o tym, że polski kodeks jest „nieubłagany dla recydywistów, zawodowców czy nałogowców”68.

IV. Liszt poświęcił karze, jej istocie, ewolucji i celom multum swoich opracowań ${ }^{69}$. Nawet podręcznik zaopatrzył w obszerny wstęp, w którym zarysował historyczny rozwój prawa karnego, szeroko uwzględniając problematykę kary ${ }^{70}$. Niemiecki uczony z upodobaniem analizował proces ewolucji kary, w którym wyróżniał trzy główne hipotetyczne etapy: „karę jako działanie impulsywne” (niem. Strafe als Triebhandlung), „obiektywizację kary” (niem. Objektivierung der Strafe) oraz „karę jako celową ochronę dóbr prawnych” (niem. Strafe als zweckbewußter Rechtsgüterschutz) ${ }^{71}$. Pod wymienionym kategoriami kryły się kolejno: pierwotna i zarazem instynktowna reakcja społeczna na naruszenia warunków życia przez jednostkę; następnie upaństwowienie kary; wreszcie nadanie karze charakteru środka służącego ochronie porządku prawnego. W ten sposób uczony przypisał karze funkcje społeczne i określał jej celowy charakter ${ }^{72}$. Należy przypomnieć, że Liszt od samego początku swej działalności w Niemczech stanowczo sprzeciwiał się dominującej ówcześnie teorii kary odwetowej (niem. Vergeltungsstrafe). Zwolennikom odpłaty zarzucał, że rozmiar kary dostosowują do pojęcia przestępstwa, tymczasem należy go dopasować do czynu danego sprawcy. Przekonywał:

Represja i prewencja nie stoją w sprzeczności. Czy pływam, bo wpadłem do wody, czy po to, aby nie utonąć? Czy biorę lekarstwo, ponieważ jestem chory, czy żeby wyzdrowieć? Czy rozciągamy kordon graniczny, ponieważ w sąsiednim kraju panuje epidemia, czy po to, aby nas oszczędziła? Czy podpieram dom, bo grozi zawaleniem, czy po to, aby się nie zawalił? Kara jest prewencją poprzez represję; albo, jak możemy równie dobrze powiedzieć: represją przez prewencję ${ }^{73}$.

67 J. Makarewicz, Kodeks..., s. 41.

${ }^{68}$ Ibidem, s. 33.

${ }^{69}$ Oprócz programu marburskiego (por. wyżej przypis 7) poświęcił zagadnieniom kary cyk1 obszernych rozpraw Kriminalpolitische Aufgaben, ZStW 9 (1889), s. 452-498 (cz. 1), s. 737-782 (cz. 2); ZStW 10 (1890), s. 51-83 (cz. 3); ZStW 12 (1892), s.161-194.

${ }^{70}$ Por. wyżej przypis 5.

71 C. Bohnert, Zu Straftheorie und Staatsverständnis im Schulenstreit der Jahrhundertwende, Pfaffenweiler 1992, s. 9-10. Autorka zwraca uwagę na darwinistyczne zabarwienie teorii kary Liszta, chociaż uczony wprost nie powoływał się na Darwina.

${ }^{72}$ S. Ehret, op. cit., s. 103-108.

${ }^{73}$ F. v. Liszt, Der Zweckgedanke, s. 44-45. 
W podręczniku Liszt definiował karę jako ,przykrość (niem. Übel) zarządzoną przez sędziego karnego wobec przestępcy z powodu przestępstwa, w celu wyrażenia społecznej dezaprobaty (niem. Unwerturteil) dla czynu i sprawcy" "74. Uczony dodawał, że kara ma dwie cechy charakterystyczne: ,po pierwsze dotyka ona sprawcy w zakresie jego chronionych prawnie interesów, ingeruje w życie, wolność, majątek, honor przestępcy; po drugie jest ona jednocześnie namacalną naganą czynu i sprawcy. W pierwszej cesze mieści się działanie szczególnoprewencyjne; w drugiej - ogólnoprewencyjne kary"75.

Liszt wymieniał wreszcie trzy bezpośrednie skutki kary: poprawę, odstraszenie oraz unieszkodliwienie. Jak już wyżej wskazano, każdy odnosił do określonej kategorii przestępców. Celowa i skuteczna ochrona dóbr prawnych wymagała bowiem, jego zdaniem, unieszkodliwienia przestępcy notorycznego, poprawy sprawcy nadającego się do poprawy oraz odstraszenia przestępcy przypadkowego ${ }^{76}$.

Makarewicz, podobnie jak Liszt, poświęcił problematyce kary bardzo wiele uwagi, analizując jej istotę, treść i cele. Identycznie jak niemiecki uczony, za stosowne uznał opracowanie ewolucji kary, którą ukazywał jako zemstę zbiorową grupy społecznej, przybierającą w rozwoju historycznym kolejne postaci. Badania polskiego profesora opierały się na gruntownych studiach etnologicznych i prawno-porównawczych, a jednocześnie miały charakter filozoficzno-prawny. O ich wnikliwości i charakterze świadczyły już sam tytuł i znaczna objętość najważniejszej pracy Makarewicza w tym zakresie - Wprowadzenia do filozofii prawa karnego $[\ldots]^{77}$.

Makarewicz wielokrotnie jasno i dobitnie wskazywał, że „kara z istoty swej jest odpłatą i niczym innym. Wszystko inne, co z karą się faktycznie łączy lub też łączyć ma, jest nieistotnym dodatkiem"78. W swym podręczniku myśli te rozwijał. Kiedy analizował różnice między karami zasadniczymi i dodatkowymi, w tych pierwszych widział sprawiedliwą odpłatę, natomiast w drugich - profilaktykę przestępczości ${ }^{79}$. Pisał:

Kara powinna pozostać sprawiedliwą odpłatą, zawierającą czynnik dolegliwości dostosowanej do przewinienia; czynniki inne, jak czynnik zabezpieczenia [...],

${ }^{74}$ F. v. Liszt, Lehrbuch (1912), s. 251.

75 Ibidem, s. 252.

76 Por. wyżej przypis 9.

77 Einführung in die Philosophie des Strafrechts auf Entwicklungsgeschichtlicher Grundlage, Stuttgart 1906. Por. nową polską edycję: J. Makarewicz, Wstęp do filozofii prawa karnego w oparciu o podstawy historyczno-rozwojowe, tłum. K. Jakubów; red. naukowa A. Grześkowiak, Lublin 2009.

78 J. Makarewicz, Prawo karne ogólne, s. 17. Identycznie w kolejnym podręczniku: Prawo karne. Wyktad..., s. 19. Podobnie w komentarzu do kodeksu karnego (Kodeks..., s. 203): „kara jest z istoty swej odpłatą, bo tym pozostanie zawsze”. Dalej (s. 176) dodawał jednak: ,[...] tkwiąca w karze odpłata ma się regulować pożytkiem społecznym przyszłym, a nie szkodą społeczną przeszłą".

79 A. Grześkowiak, Kara ..., s. 268-269. 
czynnik poprawy [...] istnieć powinny odrębnie i przejawiać się w odrębnych od zasadniczego środka karnego instytucjach prawnych ${ }^{80}$.

Od istoty kary, za którą uważał odpłatę, polski profesor odróżniał treść kary, którą utożsamiał z dolegliwościąa ${ }^{81}$ W duchu Liszta Makarewicz wywodził: „Treścią kary jest ukrócenie jednego z dóbr przestępcy, pozbawienie go życia, wolności, członka ciała, prawa przebywania wśród grupy społecznej, tej, która go spomiędzy siebie wyłącza" ${ }^{82}$. Bliskie Lisztowskiemu wyobrażeniu było też łączenie kary z naganą czy potępieniem zachowania sprawcy przez społeczeństwo, o którym polski profesor pisał: „Niewątpliwie w każdej karze tkwi ten czynnik społecznego potępienia [każda reakcja społeczna karna, będąca $\mathrm{z}$ istoty swej społeczną zemstą, opiera się na potępieniu działania sprawcy]" 83 .

Makarewicz nie odżegnywał się od wyznaczania karze celów, wręcz przeciwnie - podkreślał, iż skuteczna walka z przestępczością wymaga postawienia przed karą celów, zwłaszcza prewencji specjalnej ${ }^{84}$. Analizując system kar, pisał o prewencji m.in. w związku z karami pozbawienia wolności ${ }^{85}$, dożywotnim więzieniem ${ }^{86}$, karami dodatkowymi ${ }^{87}$, warunkowym zwolnieniem ${ }^{88}$, a zwłaszcza w kontekście środków zabezpieczających, o których mowa poniżej. Podkreślał, że zadaniem kar czy środków izolacyjnych jest oddziaływanie na psychikę sprawcy, odstraszenie go i (lub) poprawienie, a także wywołanie przemiany duchowej ${ }^{89}$.

V. Liszt nie był ani ojcem, ani rzecznikiem koncepcji dwutorowości w prawie karnym ${ }^{90}$. Przekonanie o słuszności zróżnicowanej reakcji karnej nie było mu jednak obce. Już w Programie marburskim Liszt zaznaczał, że

80 J. Makarewicz, Prawo karne. Wyktad..., s. 235.

${ }^{81}$ A. Grześkowiak, Kara ..., s. 261. Por. Por. M. Wąsowicz, Nurt socjologiczny w polskiej myśli prawnokarnej, Warszawa 1989, s. 89-90.

82 J. Makarewicz, Zbrodnia, s. 88.

83 J. Makarewicz, Prawo karne ogólne, s. 266.

${ }^{84}$ A. Grześkowiak, Kara ..., s. 264-267. Lwowski uczony stale zwracał uwagę na konieczność „zabezpieczenia społeczeństwa” przed przestępczością, zwłaszcza zawodową czy tzw. nałogową - por. J. Makarewicz, Kodeks, s. 27, 40, 128, 178, 201, 205 i in. Wielokrotnie odwoływał się do „względów kryminalno-politycznych”, „podkładu kryminalno-politycznego”, czyli do celowego oddziaływania kary - por. ibidem, s. 36, 135, 183, 190-191.

85 J. Makarewicz, Kodeks..., s. 201.

${ }^{86}$ Ibidem, s.128: „odgrywa (ono) rolę zabezpieczenia społeczeństwa przez trwałe odciągnięcie go (skazańca) od życia społecznego".

${ }^{87}$ Ibidem, s.178. Por. s. 124-125: „na plan pierwszy wysuwa się wzgląd na ochronę społeczeństwa na przyszłość".

${ }^{88}$ Ibidem, s. 183-184.

${ }^{89}$ Ibidem, s. 40. Por. też s. 36.

${ }^{90}$ Por. niżej przypis 99. 
unieszkodliwienie niepoprawnego przestępcy powinno polegać na uwięzieniu go na czas nieokreślony. Uczony oceniał, zgodnie z obowiązującym ustawodawstwem, projektami reformy prawa oraz ustaleniami doktryny, że uwięzienie niepoprawnego przestępcy polega w istocie na „karnej niewoli” (Strafknechtschaft). W pełni akceptował taki stan rzeczy, wskazując, że omawiana kara ma być związana z przymusem pracy i najsurowszą dyscypliną, łącznie z takimi środkami dyscyplinarnymi jak chłosta, pojedyncza cela, ciemnica, najsurowszy post ${ }^{91}$. Był to postulat bezwzględnego traktowania przestępców niepoprawnych ${ }^{92}$.

Liszt dostrzegał podobieństwo między karami izolacyjnymi, stosowanymi wobec niepoprawnych przestępców, a izolacją sprawców chorych psychicznie i niebezpiecznych dla ogółu. W rozprawie z $1897 \mathrm{r} .{ }^{93}$ przyznawał, że nie znajduje podstaw teoretycznych dla różnicowania tych sankcji ${ }^{94}$. Za tym stwierdzeniem nie poszedł jednak postulat wprowadzenia wobec obu wymienionych kategorii sprawców jednej reakcji karnej w postaci środka zabezpieczającego. Liszt tłumaczył, że różnica między „przestępstwem” a „szaleństwem” tak silnie zakorzeniła się w niemieckiej kulturze prawnej, że dopiero ustawodawca może i powinien ostrożnie i stopniowo zmieniać ten stan rzeczy ${ }^{95}$.

Liszt nie zmienił swego stosunku do środków zabezpieczających nawet na początku XX w., kiedy zapoznał się i recenzował najnowsze zamierzenia reformy prawa karnego, względnie projekty kodeksów karnych w Europie, a także w samych Niemczech, które przewidywały dwutorową reakcję karną. Nadal podkreślał sporny charakter środków zabezpieczających oraz niemożność ich jasnego przeciwstawienia karom. W podręczniku swym pisał w tym czasie:

Stosunek środka zabezpieczającego do kary jest pełen sprzeczności. Ostre przeciwstawienie obu pojęć, które znalazło się u v. Birkmeyera ${ }^{96} \mathrm{i}$ innych, kłóci się z rzeczywistością. [...] Gdy środek zabezpieczający wiąże się z popełnieniem

91 F. v. Liszt, Der Zweckgedanke, s. 39-40.

92 W. Naucke, op. cit., s. 247.

93 F. v. Liszt, Die strafrechtliche Zurechnungsfähigkeit. Vortrag, gehalten am 4. August 1896 auf dem III. Internationalen Psychologen-Kongress, ZStW 17 (1897), s. 70-84.

94 Ibidem, s.82: „So komme ich zu dem m. M. nach unabweislichen Ergebnisse: Die Unterscheidung zwischen der Sicherungsstrafe gegen unverbesserliche Verbrecher und der Verwahrung gemeingefährlicher Geisteskranker ist nicht nur praktisch im Wesentlichen undurchführbar, sie ist auch grundsätzlich zu verwerfen".

95 A. Koch, op. cit., s.138-139.

96 Karl von Birkmeyer (1847-1920), przedstawiciel klasycznej szkoły prawa karnego, był przeciwnikiem naukowym Liszta, autorem głośnej pracy Was lässt von Liszt vom Strafrecht übrig? (Co von Liszt zostawia z prawa karnego?), wydanej w 1907 r. Por. D. Lang-Hinrichsen, Birkmeyer, Karl von, Neue Deutsche Biographie 2 (1955), s. 258. W polskiej literaturze przedmiotu zob. E.S. Rappaport, W obliczu reformy (Birkmeyer-Liszt-Haase), Gazeta Sądowa Warszawska 7-12 (1907), s. 103 i n. 
czynu karygodnego, może z pewnością mieścić w sobie istotę kary (przykrość związaną z dezaprobatą czynu); nawet z punktu widzenia teorii odpłaty. [...] Obie instytucje prawne są jak dwa przecinające się koła: czysta kara odwetowa i czysty środek zabezpieczający stoją wobec siebie w sprzeczności; jednak w części wspólnej środek zabezpieczający może wejść w miejsce kary (przejąć jej rolę) i odwrotnie. Takie stanowisko zajmują trzy projekty (niemiecki, austriacki, szwajcarski - przyp. autorki)...97

Będąc doświadczonym prawnikiem, Liszt dostrzegał ponadto, że w wypadku stosowania środków zabezpieczających może powstać konflikt między potrzebą ochrony społeczeństwa a gwarancją indywidualnej wolności. Nie analizował tej kwestii. Pod koniec życia wygłosił jedynie przypuszczenie, że przyszły rozwój prawa karnego doprowadzi do wyłączenia środków zabezpieczających z prawa karnego i przeniesienia ich do ustaw szczególnych ${ }^{98}$.

Makarewicz był gorącym orędownikiem środków zabezpieczających, podobnie jak wielu innych ówczesnych prawników szukających nowych form zapobiegania wzrastającej przestępczości. Wzory czerpał z doktryny, ustawodawstwa i praktyki innych państw. W nauce prawa za ojca idei środków zabezpieczających, stosowanych obok kar, uchodzi szwajcarski profesor Karl Stooss, działający w Austrii, autor głośnego projektu szwajcarskiego kodeksu karnego z 1893 r. ${ }^{99} \mathrm{Na}$ ten ostatni powoływał się Makarewicz, porównując propozycje Stoossa z nowszymi projektami niemieckim i austriackim ${ }^{100}$. Polski uczony przypominał ponadto o dawnych środkach służących walce z chroniczną lub niebezpieczną przestępczością ${ }^{101}$.

Makarewicz nie dawał szerszego uzasadnienia dogmatycznego dla dualnego systemu reakcji karnej. Podział między karami a środkami zabezpieczającymi usiłował oprzeć na kryterium celowości. Tłumaczył: „Środek karny jest aktem reakcji społecznej o typie represyjnym (zemsta społeczna), środek zabezpieczający jest aktem reakcji społecznej o typie prewencyjnym, zapobiegawczym" 102 . Wyraźnie wskazywał, że nowe środki reakcji karnej mają być

97 F. v. Liszt, Lehrbuch (1912), s. 253.

98 S. Ehret, op. cit., s. 90. Stanowisko to wyraził uczony w rozprawie 'Die Sichernden Maßnahmen' in den drei neuen Strafgesetzentwürfen, Archiv für Rechts- und Wirtschaftsphilosophie $3(1909 / 10)$, s. 610 i n.

99 Por. Kaenel P., Die kriminalpolitische Konzeption von Carl Stooss im Rahmen der geschichtlichen Entwicklung von Kriminalpolitik und Straftheorien, Bern 1981, s. 97 i n.

${ }^{100}$ Wszystkie trzy projekty szczegółowo przedstawił inny uczeń Liszta, sędzia i docent Uniwersytetu Jagiellońskiego J. Reinhold, Środki zabezpieczające przeciw niepoprawnym i anormalnym przestępcom, ze szczególnym uwzględnieniem nowych projektów kodeksów karnych, Przegląd Prawa i Administracji 1912, s. 391-450.

101 J. Makarewicz, Prawo karne ogólne, s. 284; idem, Prawo karne. Wykład..., s. 294-296.

102 J. Makarewicz, Kodeks..., s. 51. Por. idem, Prawo karne. Wykład, s. 293: „Pozostają przeto środki zabezpieczające, samoistne, występujące obok środków karnych. Sprawa jest aktualną tym więcej, że nie zawsze chodzi o osobnika, którego można zasądzić na karę i tę karę odpowiednio 
stosowane obok lub zamiast kary, innymi słowy, że powinny być uzupełnieniem lub surogatem środków karnych ${ }^{103}$.

Ogólnie rzecz biorąc, lwowski uczony reprezentował stanowisko pragmatyczne, kierując się wymogami skutecznej polityki kryminalnej i odwołując do doświadczeń innych krajów. Wyodrębnienie środków zabezpieczających z kary uznał po prostu za konieczne; ich celem miało być zabezpieczenie społeczeństwa, a treścią - izolacja ${ }^{104}$. Makarewicz wyrażał przekonanie, że „środki zabezpieczające to zjawisko nowe, znamię XX wieku, tak jak wiara w więzienia i systemy penitencjarne wypełnia wiek XIX"105. W podręczniku z 1924 r. jasno wskazał kategorie przestępców, przed którymi należało chronić społeczeństwo przy pomocy środków zabezpieczających, wyliczając: przestępców zawodowych, nałogowych, recydywistów, częściowo anormalnych, alkoholików, osoby czujące wstręt do pracy ${ }^{106}$. Stanowczo twierdził, że walka z tego rodzaju przestępczością wymaga sięgnięcia „,do arsenału nowych sposobów przeciwdziałania przyrostowi zjawisk społecznej patologii”"107.

Znane są pełne zaangażowania wystąpienia Makarewicza na posiedzeniach Senatu RP z lat 1928-1931, kiedy był członkiem izby wyższej. Jego apele o wprowadzenie środków zabezpieczających wobec przestępców niepoprawnych i chorych psychicznie jeszcze przed wejściem w życie gotowego niemal polskiego kodeksu karnego - pozostały bezskuteczne ${ }^{108}$. Nie pomogły nawet demagogiczne wystąpienia profesora-senatora w rodzaju: „Zamknięcie na dłuższy czas kilku tysięcy zawodowców oznacza zmniejszenie ilości przestępstw dokonywanych - przynajmniej o połowę"109.

Makarewicz długo zastanawiał się nad czasem trwania środków zabezpieczających. Ogólnie rzecz biorąc zakładał, podobnie jak Karl Stooss, że czas

ukształtować, chodzi także o jednostki niebezpieczne, które z powodu braku warunków odpowiedzialności w ogóle (lub w chwili dokonania) nie mogą być przedmiotem kary”.

103 J. Makarewicz, Kodeks..., s. 28: „Subiektywizm w dziedzinie poczytania winy, a humanitaryzm w dziedzinie stosowania środków karnych wymagają odpowiednika w środkach zabezpieczających. Środki zabezpieczające mogą być uzupełnieniem środków karnych, mogą być także ich surogatem". Por. idem, Wzrost..., s. 168.

104 Por. F. Ciepły, op. cit., s. 291-292.

105 J. Makarewicz, Kodeks..., s. 38. Por. ibidem, s. 201: „(...) z chwilą bankructwa kary pozbawienia wolności, jako środka, który miał przestępcę poprawiać czy odstraszać, stanąć musiało społeczeństwo wobec problemu, co należy uczynić, aby poza wymiarem sprawiedliwości w postaci odpłaty osiągnąc jeszcze ochronę społeczeństwa przed przestępczością".

106 Makarewicz wielokrotnie podkreślał konieczność ochrony społeczeństwa „przed plagą nowożytnego życia społecznego: przed przestępstwem zawodowym czy nałogowym” - por. Kodeks..., s. 27 i 39.

107 Ibidem, s. 27.

108 J. Makarewicz, Wzrost..., s.163-174. Por. też wyżej przypis 52.

109 Ibidem, s. 170. Por. ibidem, s.168: „Nikt chyba na początku czwartego dziesiątka XX wieku nie oddaje się złudzeniom, by szablonowy wymiar sprawiedliwości karnej prowadził do zmniejszenia przestępczości. (...) Nowożytny ustawodawca ogląda się za skuteczniejszym sposobem rozprawiania się ze sprawcami przestępstwa". 
trwania izolacji przestępcy w ramach środka zabezpieczającego nie może być ustawowo wskazany czy ograniczony ${ }^{110}$. Logika podpowiadała mu, że izolacja powinna trwać „tak długo, jak długo zachodzi tego potrzeba, a więc jak długo alkoholik nie nabierze wstrętu do alkoholu, próżniak nie zmieni się w pracowitego, chory nie wyleczy się itd." 111 . Analizując wzory innych państw, stwierdził, że stoją one konsekwentnie tylko na stanowisku bezterminowej izolacji osób niepoczytalnych całkowicie lub częściowo. Ostatecznie, biorąc pod uwagę kulturę prawną polskiego społeczeństwa, rekomendował do kodeksu karnego środki zabezpieczające jako sankcje uzupełniające, przy czym minimalny czas ich trwania określono na 1-5 lat, a o maksymalnym wymiarze decydować mieli sędziowie ${ }^{112}$.

VI. Biografie Franza von Liszta i Juliusza Makarewicza, mimo wielu różnic, wykazują pewne zaskakujące analogie. Wspólnym mianownikiem w obu życiorysach była działalność naukowa połączona z organizacyjną i polityczną - w ławach parlamentarnych. Zbieżność widoczna jest też w samym cyklu działalności naukowej - Liszt wykładał i tworzył w sumie przez blisko pół wieku, z tego 40 lat w Niemczech; Makarewicz rozpoczął działalność naukową w okresie zaborów i uprawiał ją przez ponad pół wieku, z tego we Lwowie - przez ponad 40 lat.

Program Liszta opierał się na idei kary celowej, zorientowanej prewencyjnie oraz typologii przestępców i dostosowanych do niej kar pozbawienia wolności. Istotnym motywem była w jego doktrynie polityka kryminalna. Podstawę programu Makarewicza stanowiła kara traktowana jako sprawiedliwa odpłata, lecz mająca służyć prewencji specjalnej. Głównym lejtmotywem obok kary stały się $\mathrm{w}$ doktrynie polskiego profesora środki zabezpieczające o charakterze izolacyjnym, które miały chronić społeczeństwo przed przestępcami niebezpiecznymi.

Mimo wielu rozbieżności, w programach i polskiego, i niemieckiego uczonego pojawiły się podobne elementy. Wspólnym mianownikiem była przede wszystkim krytyka dotychczasowych sposobów walki z przestępczością oraz towarzyszące jej dążenie do znalezienia nowych skutecznych dróg walki z recydywą i przestępczością zawodową. Zapewne te motywy zadecydowały o tym, że Juliusz Makarewicz nawiązał wprost do dziedzictwa Franza

110 J. Makarewicz, Kodeks..., s. 60: „społeczeństwo stosuje je (środki zabezpieczające) według swego uznania, nie krępowane względami na to, czy stosowanie ich było w ogóle zapowiedziane (...)”. Por. idem, Wzrost..., s.173: (zadaniem środka zabezpieczającego” jest) „odciąć trwale od społeczeństwa jednostkę niebezpieczną, ze względu na swój ustrój psychofizyczny, zagrażający spełnianiem czynów karygodnych". K. Stooss różnicę między terminami kar i środków zabezpieczających oparł na kryterium winy, pisząc: „,czas kary (...) określa wina sprawcy; czas środka zabezpieczającego - jego cel” - por. P. Kaenel, op. cit., s. 118 oraz F. Ciepły, op. cit., s. 292-293.

111 J. Makarewicz, Prawo karne. Wyktad..., s. 296.

112 Por. F. Ciepły, op. cit., s. 300. 
v. Liszta, a w szczególności do jego typologii przestępców, w tym pojęcia niepoprawnego przestępcy i postulatu jego unieszkodliwienia. Ani niemiecki, ani polski profesor nie zdołał natomiast stworzyć szerszego teoretycznego uzasadnienia poszczególnych typów przestępców - obaj poprzestali na wskazaniu ich konkretnych przykładów. Makarewicz zaadoptował natomiast bezpośrednio Lisztowską formułę o kodeksie karnym jako magna charta sprawcy przestępstwa.

Najważniejsze różnice $\mathrm{w}$ ideach zasłużonego Niemca i wielkiego Polaka polegały na odmiennej wizji systemu reakcji karnej. Franz v. Liszt z dystansem obserwował wzrastającą popularność środków zabezpieczających. Sam od lat dostrzegał i przyznawał, że funkcje kary izolacyjnej, odbywanej przez niepoprawnego więźnia oraz cele odosobnienia stosowanego wobec niebezpiecznego sprawcy chorego psychicznie - są do siebie podobne; nie widział jednak potrzeby dwutorowej represji karnej. Makarewicz, inspirowany ideologią szkoły socjologicznej w Europie, nowymi projektami reform prawa karnego i zagraniczną praktyką penitencjarną, przekonywał o celowości i konieczności orzekania obok zwykłych kar - środków zabezpieczających.

W osiągnięciach naukowych obu prawników zabrakło symetrii w praktycznej realizacji ich teorii. O ile Juliusz Makarewicz zdołał zrealizować wiele ze swych koncepcji w polskim kodeksie karnym z 1932 r., Franz v. Liszt - $\mathrm{z}$ różnych powodów - najpierw nie został zaproszony do żadnej z niemieckich komisji reformy prawa karnego, a następnie nie doczekał zmian inspirowanych jego programem, które wprowadzono w republice weimarskiej już po jego śmierci w $1919 \mathrm{r}$.

W recenzji podręcznika Franza von Liszta młody Juliusz Makarewicz napisał: ,[...] nauka tylko zyskuje, biorąc bowiem cum grano salis jego (Liszta) pomysły, wybiera spokojnie rzeczywiście dobre, pozostawiając na uboczu słabe" 113 .

Wydaje się, że w swej twórczości oraz swoim opus magnum - kodeksie karnym - polski uczony stosował się do tej zasady, zapożyczając z dorobku Liszta i jego szkoły te wątki, które uważał za odpowiednie w otaczającej go rzeczywistości. W ten sposób, łącząc różne elementy, tworzył oryginalną syntezę - program polskiej szkoły socjologicznej prawa karnego.

113 Recenzja (por. przypis 1), s. 330-331. 


\title{
JULIUSZ MAKAREWICZ AND FRANZ VON LISZT. A COMPARATIVE ANALYSIS
}

\begin{abstract}
Summary
The study is a comparative analysis of the main elements of two criminal law systems developed by two different lawyers: Franz von Liszt (1851-1919) and Juliusz Makarewicz (1872-1955). Both belonged to the leading representatives of the modern sociological school of law of which von Liszt, a German, is believed to be its progenitor, and Makarewicz its main representative in Poland. They criticized the existing methods of fighting crime and were searching for new efficient solutions. Basing their research on comparable typology of criminals, they developed a concept of an incorrigible criminal. Liszt and Makarewicz also emphasised the nullum crimen sine lege rule and called the penal code a magna charta for criminals. While Liszt postulated specific deterrence to be the primary aim of punishment and recommended introduction of uniform penalties, even for recidivists, Makarewicz regarded punishment to be an act of retribution and believed that protective measures should be introduced into the penal code alongside imprisonment. However, while the former was not involved in any kind of legislative work, the latter went down in history as the creator of the Polish penal code of 1932.
\end{abstract}

\section{MAKAREWICZ PAR RAPPORT À LISZT. UNE TENTATIVE D'ANALYSE COMPARATIVE}

\section{Résumé}

La présente étude est une analyse comparative de certains éléments majeurs de deux systèmes du droit pénal: celui du juriste allemand, Franz von Liszt (1851-1919) et du juriste polonais, Juliusz Makarewicz (1872-1955). Les deux représentent la même école sociologique du droit pénal, seulement von Liszt passe pour son père, alors que Makarewicz est son principal représentant en Pologne. Les deux juristes critiquent les méthodes utilisées dans la lutte contre la délinquance et sont à la recherche de nouvelles pratiques, efficaces, permettant de la combattre. Les deux juristes s'appuient sur une typologie de délinquants et le concept du délinquant incorrigible. Les deux hommes soulignent par ailleurs l'importance de la règle nullum crimen sine lege et nomment de la loi pénale magna charta pour le délinquant. Liszt est partisan de la prévention spéciale, étant la finalité de la peine; Makarewicz, quant à lui, croit que la sanction est avant tout une juste revanche. Liszt est pour une punition criminelle homogène, même pour les délinquants incorrigibles. Makarewicz par contre essaie de convaincre que les délinquants incorrigibles doivent être condamnés à que l'on appelle des mesures de sûreté, devant être intégrées dans le code pénal avec des 
peines classiques privatives de liberté. Les deux juristes travaillent pendant un demi siècle dans un milieu non seulement scientifique mais également organisationnel et politique. Liszt n'a pas participé aux travaux de codification, par contre Makarewicz s'inscrira dans l'histoire en tant que père du code pénal polonais de 1932. 